\title{
OCENA MORALNA ROZWODÓW W SPOŁECZEŃSTWIE POLSKIM A DUSZPASTERSTWO RODZIN
}

Jednym z istotnych przymiotów małżeństwa jest nierozerwalność. Racją tego przymiotu jest dobro małżonków, ponieważ nierozerwalność małżeństwa zapewnia jego trwałość, dzięki czemu możliwy jest stały rozwój komunii osób, stanowiącej istotę jedności małżeńskiej. Nierozerwalność małżeństwa wymagana jest także dla dobra społeczeństwa, dlatego że trwałe związki małżeńskie, będąc początkiem i podstawą społeczności ludzkiej, przyczyniają się do wzmocnienia i pogłębienia ładu społecznego ${ }^{1}$. Małżeństwo jest więc podstawowym elementem wspólnego dobra każdego społeczeństwa. Biorąc pod uwagę te prawdy oraz odwołując się do mocy prawa Bożego, wyrażonego w zamyśle Bożym wobec małżeństwa, prawo Kościoła katolickiego stwierdza, że małżeństwo zawarte i dopełnione nie może być rozerwane ani wewnętrznie, czyli przez wolę zainteresowanych stron, ani zewnętrznie, czyli przez jakąkolwiek władzę doczesną ${ }^{2}$.

* Ks. dr hab. Jerzy Kułaczkowski pracuje w Instytucie Studiów nad Rodziną UKSW w Warszawie jako kierownik Katedry Pedagogiki Rodziny.

${ }^{1}$ Apostolicam actuositatem. Dekret o apostolstwie świeckich, nr 11, w: Sobór Watykański II. Konstytucje. Dekrety. Deklaracje, tekst polsko-łaciński, Poznań 1986, s. 597; Jan Paweł II, Familiaris consortio. Adhortacja apostolska o zadaniach rodziny chrześcijańskiej w świecie wspótczesnym, nr 42, w: Posoborowe dokumenty Kościota katolickiego o matżeństwie $i$ rodzinie, t. 1 , red. K. Lubowicki, Kraków 1999, s. 183.

${ }^{2}$ Kodeks Prawa Kanonicznego, tekst łacińsko-polski, Poznań 1984, kan. 1141. 
Uwzględniając przeobrażenia dokonujące się współcześnie w społeczeństwie polskim, powstaje pytanie o ocenę moralną rozwodów przez Polaków, która zarazem może być traktowana jako kryterium akceptacji nierozerwalności małżeństwa, oraz zadania duszpasterstwa rodzin wobec tej sytuacji.

\section{ROZWÓD A NIEROZERWALNOŚĆ MAŁŻEŃSTWA W NAUCZANIU KOŚCIOŁA}

W świetle nauczania Kościoła katolickiego, nierozerwalność małżeństwa polega na tym, że związku małżeńskiego nie można zawierać na określony czas, lecz do końca życia jednej ze stron. Z mocy prawa Bożego małżeństwo zawarte pomiędzy ochrzczonymi i dopełnione nie może być rozerwane ani przez wolę zainteresowanych stron, czyli „wewnętrznie”, ani przez jakąkolwiek władzę doczesną, czyli „zewnętrznie”” . Jest to równoznaczne z tym, że rozwód sprzeciwia się nierozerwalności małżeństwa ${ }^{4}$.

Za nierozerwalnością małżeństwa opowiadali się Ojcowie Kościoła. Według św. Augustyna wykluczona zostaje jakakolwiek możliwość rozwiązania małżeństwa, ponieważ jest ono znakiem rzeczywistości nadprzyrodzonej. Jeśli wspólnota małżeńska miałaby być rozwiązywalna, wówczas zostałby zburzony jej sakralny symbolizm. W związku z tym, treścią małżeństwa staje się moralny obowiązek, czyli polecenie do wykonania. To zobowiązanie zostaje wzmocnione sakralnym symbolizmem małżeństwa.

Prawda o nierozerwalności małżeństwa nie była podważana do czasów nowożytnych. Przykładem tego może być doktrynalne orzeczenie Sobóru Florenckiego (1438-1445), który stwierdził, że ponieważ małżeństwo wyobraża nierozerwalny związek Chrystusa z Kościołem, to samo jest nierozerwalne ${ }^{5}$. Nieco dalej w tym samym fragmencie Dekretu do Ormian znajduje się zdanie, że małżonkowie powinni dochować sobie wierności. W takim samym duchu o nierozerwalności małżeńskiej wypowiedział się Sobór Trydencki, dodając, że przymiot ten został nadany temu związkowi przez Boga już u samego początku zaistnienia małżeństwa ${ }^{6}$. Jest ono więc nierozerwalne niezależnie od okoliczności ${ }^{7}$, nawet w sytuacji, gdyby jedno z małżonków dopuściło się cudzołóstwa.

${ }^{3}$ M. Żurowski, Kanoniczne prawo matżeńskie Kościoła katolickiego, Katowice 1987, s. 61.

${ }^{4}$ T. Pawluk, Przestanki nierozerwalności matżeństwa, Prawo Kanoniczne 26 (1983), nr 1-2, s. 221; KPK, kan. 1056.

${ }^{5}$ Breviarium fidei. Wybór doktrynalnych wypowiedzi Kościoła, opr. S. Głowa, I. Bieda, Poznań 2001, VII 593 (dalej cyt. jako BF).

${ }^{6} B F$, VII 594.

${ }^{7} B F, 602,604,605$. 
Encyklika Leona XIII Arcanum Divinae Sapientiae wiele miejsca poświęca nierozerwalności małżeństwa ${ }^{8}$. W encyklice tej papież stwierdza, że małżeństwo między chrześcijanami jest umową nierozwiązalną i sakramentem, dlatego Kościół wyłącznie sobie zastrzega prawo decyzji w tej dziedzinie ${ }^{9}$. Leon XIII przedstawia apologię rodziny takiej, jaką ją określił Chrystus i Kościół, poprzez ukazanie dobrodziejstw porządku społecznego. Pomimo dynamiki zawartej $\mathrm{w}$ tym dokumencie, zabrakło w nim, dla pełniejszego obrazu, sprecyzowania podstaw duchowości małżeństwa i rodziny. Arcanum jest więc nauczaniem Kościoła, koncentrującym się przede wszystkim na obronie praw życia małżeńskiego pod kątem dobra społecznego.

Do nierozerwalności małżeństwa nawiązał także Pius XI w encyklice Casti connubi. Według tego dokumentu małżeństwo ważnie zawarte pomiędzy ochrzczonymi i dopełnione nie może zostać rozwiązane przez władzę świecką. Dlatego instytucja rozwodów nie może mieć zastosowania ${ }^{10}$. Nierozerwalność małżeństwa wypływa z woli Bożej, wyrażonej w prawie Bożym i naturalnym. Następnie wypływa ze stosunku małżeństwa do Chrystusa i Kościoła, czyli z faktu, że małżeństwo jest sakramentem. Na rzecz nierozerwalności przemawiają także dobra, jakie z niej wynikają, zarówno dla małżonków (trwałość, ofiarne oddanie, wzajemne zjednoczenie, prawdziwa miłość, wzajemna pomoc, wierność, zabezpieczenie przed grzechem nieczystości), jak i dla ich potomstwa (wychowania i opieki). Ponadto nierozerwalność małżeńtwa zapewnia społeczeństwu i państwu, szczęście i pomyślnośćn ${ }^{11}$.

Również ostatni z soborów, którym był Sobór Watykański II, podjął temat nierozerwalności w swoim nauczaniu, czego wyrazem są teksty z konstytucji duszpasterskiej o Kościele w świecie współczesnym, stwierdzające, że zjednoczenie małżonków wymaga pełnej wierności i dąży do nieprzerwanej jedności ich współżycia ${ }^{12}$. Podobną treść zawiera fragment z dekretu o apostolstwie

${ }^{8}$ Jedną z głównych przyczyn jej powstania był wszczęty na nowo spór wokół ponownego rozpowszechniania się „legalnych" rozwodów. Warto tu przypomnieć, że to właśnie prawodawstwo francuskie z 1792 roku, a więc w czwartym roku trwania rewolucji francuskiej, po raz pierwszy w świecie wprowadziło śluby cywilne. Następstwem takiego postępowania było zaprzestanie traktowania przez państwo związku mężczyzny i kobiety jako aktu wcześniejszego od zaistnienia społeczeństwa i przewyższającego z racji rzeczywistości, jakie angażuje porządek czysto doczesny, do którego należy społeczeństwo i państwo. Od tej pory zlaicyzowane małżeństwo nie wzniesie się już ponad przyjemność człowieka, uwarunkowaną często egoistycznym nastawieniem, jego kaprysami i niestałością.

${ }^{9}$ Należy zaznaczyć, że encyklika ta nie była pierwszą wypowiedzią Kościoła w sprawie ślubów cywilnych. Już bowiem Pius VI w 1794 roku, a po nim Pius VII (1803), Grzegorz XVI (1832) i Pius IX $(1851,1852)$ usilnie przypominali, że małżeństwo jest instytucją przekraczającą kompetencje społeczeństwa świeckiego, jeśli chodzi o jego najistotniejsze cechy.

${ }^{10}$ Pius XI, Casti connubi. Encyklika o matżeństwie chrześcijańskim, Kraków 1931, s. 20; $B F$, VII $613,614$.

${ }^{11}$ Tamże, s. 22-23, 52-53.

${ }^{12}$ Gaudium et spes. Konstytucja duszpasterska o Kościele w świecie wspótczesnym, 
świeckich: „zawsze było obowiązkiem małżonków, a dziś stanowi najważniejszą część ich apostolstwa, ukazywać i potwierdzać swoim życiem nierozerwalność i świętość węzła małżeńskiego"13.

Sobór Watykański II poucza, że nierozerwalność małżeństwa nie powinna podlegać żadnym uwarunkowaniom: „małżeństwo trwa jako połączenie i wspólnota całego życia i zachowuje wartość swoją oraz nierozerwalność nawet wtedy, gdy brakuje tak często pożądanego potomstwa"14. Nierozerwalność ta jest podyktowana głównie ze względu na miłość małżeńską, która jest pierwszorzędnym celem związku małżeńskiego. W dalszej kolejności dopełnieniem tego celu jest zrodzenie potomstwa. Brak potomstwa nie czyni jednak małżeństwa rozerwalnym. Tekst KDK przestrzega nawet przed rozerwaniem małżeństwa: "gdzie zrywa się intymne pożycie małżeńskie, tam nierzadko wierność może być wystawiona na próbę, a dobro potomstwa zagrożone. Wtedy bowiem grozi niebezpieczeństwo zarówno wychowaniu dzieci, jak i zdecydowanej woli przyjęcia dalszego potomstwa"15. Należy zauważyć, że zasadnicza argumentacja wykorzystywana w tekstach soborowych $(49,50,51)$ nie pochodzi z refleksji filozoficznej czy racji biologiczno-psychologicznych, ale opiera się na Objawieniu Bożym i na interpretacji tradycji kościelnej.

Pojęcie jedności małżeństwa, o której mówią powyższe fragmenty dokumentów Soboru Watykańskiego II, łączy się z jego monogamicznym charakterem ${ }^{16}$, to znaczy, że zawarty związek pozwala na pożycie małżeńskie jednego mężczyzny z jedną kobieta, wyklucza natomiast wielożeństwo, czyli poligamię, która może występować w dwojakiej postaci. Pierwszą jest poligynia, czyli sytuacja, w której jeden mężczyzna żyje z wieloma kobietami ${ }^{17}$, drugą jest poliandria, czyli sytuacja, w której kobieta współżyje z wieloma mężczyznami ${ }^{18}$. Ponieważ w jednej i drugiej formie poligamii brak owej równości, jakiej wymaga od obu stron natura tej szczególnej umowy, którą nazywamy małżeństwem ${ }^{19}$, dlatego obie z nich są niedopuszczalne w Kościele katolickim. Małżeństwo monogamiczne jest zgodne z naturą ludzką i taka forma występuje u ludów pierwotnych ${ }^{20}$.

nr 48, w: Sobór Watykański II. Konstytucje. Dekrety. Deklaracje, tekst polsko-łaciński, Poznań 1986, s. 905.

${ }^{13}$ Apostolicam actuositatem. Dekret o apostolstwie świeckich, nr 11, w: Sobór Watykański II. Konstytucje. Dekrety. Deklaracje, s. 597.

${ }^{14} \mathrm{KDK}, 50$.

${ }^{15} \mathrm{KDK}, 51$.

${ }^{16} \mathrm{KDK}, 47$.

${ }_{17}$ Zakaz praktykowania poligamii został sformułowany przez Kościół na II Soborze Lyońskim w 1274 roku, który był XIV w kolejności i jest zawarty w tak zwanym „wyznaniu wiary Michała Paleologa"; BF, IX 38.

${ }^{18}$ W. Góralski, Kościelne prawo małżeńskie, Płock 1987, s. 13.

${ }^{19}$ P. Chretien, De matrimonio, praelectiones, Metis 1937, s. 49.

${ }^{20}$ W. Wundt, Elemente der Volkerpsychologie, Leipzig 1912, s. 49n.; W. Schmidt, Die 
Stanowisko soborowe o nierozerwalności małżeństwa zostało podtrzymane przez późniejsze dokumenty Kościoła. Przykładem tego jest list Haec sacra congregatio, opublikowany w 1973 roku przez Kongregację Nauki Wiary i skierowany do biskupów, w którym zawarte jest wezwanie do czujności $\mathrm{w}$ związku z rozpowszechnianiem opinii przeciwstawiających się lub podających w wątpliwość dotychczasową naukę Kościoła w tym przedmiocie ${ }^{21}$.

Wiele uwagi nierozerwalności małżeństwa poświęcił w swoim nauczaniu Jan Paweł II, co widoczne jest już w jednym z jego pierwszych dokumentów, jakim jest adhortacja apostolska Familiaris consortio. Papież stwierdza w nim, że komunia małżeńska charakteryzuje się nie tylko jednością, ale również nierozerwalnością. Ta nierozerwalność jest zakorzeniona w osobowym i całkowitym obdarowaniu się małżonków, która znajduje swoje ostateczne uzasadnienie w zamyśle Bożym, wyrażonym w Objawieniu. Bóg chce nierozerwalności małżeństwa i daje ją jako znak i wymóg miłości wiernej, którą On darzy człowieka i którą Chrystus żywi dla Kościoła ${ }^{22}$. Słowa przysięgi małżeńskiej wskazują, że trwałość, czyli nierozerwalność ich związku, jest wspólnym dobrem małżonków²3. Jan Paweł II podkreśla, że całkowity dar z ciała byłby zakłamaniem, jeśliby nie był znakiem i owocem pełnego oddania osobowego, w którym jest obecna cała osoba, również w swym wymiarze doczesnym, jeżeli człowiek zastrzega coś dla siebie lub rezerwuje sobie możliwość zmiany decyzji w przyszłości²4.

Dzięki swojej trwałości małżeństwo może się skutecznie przyczynić do pełnej realizacji chrzcielnego powołania małżonków, gdyż jest ono stanem życia, drogą chrześcijańskiej świętości, prowadzącej do chwalebnego zmartwychwstania i uczestnictwa w Królestwie Niebieskim. Dlatego nierozerwalność małżeństwa wyraża wymiar jego obiektywnej natury i nie jest tylko rzeczywistością subiektywną. Dostrzeganie w nierozerwalności tylko jakiegoś ideału, a nie normy prawa naturalnego byłoby błędem ${ }^{25}$. Niezrozumienie tej cechy związku małżeńskiego równa się niezrozumieniu małżeństwa w jego istocie ${ }^{26}$. Prawda

menschliche Gesellschaft. Der Mensch alter Zeiten-III, Regensburg 1924, s. 138; E. Westermark, Historie du mariage, Paris 1943.

${ }^{21}$ Kongregacja Nauki Wiary, Haec sacra congregatio. List o nierozerwalności matżeństwa, w: Posoborowe dokumenty Kościoła katolickiego o matżeństwie i rodzinie, t. 1, red. K. Lubowicki, Kraków 1999; W. Góralski, Kościelne prawo matżeńskie, s. 15.

${ }^{22}$ Jan Paweł II, Familiaris consortio. Adhortacja apostolska o zadaniach rodziny chrześcijańskiej w świecie wspótczesnym, nr 20, w: Posoborowe dokumenty Kościoła katolickiego o matżeństwie i rodzinie, s. 154-155.

${ }^{23}$ Obrzędy sakramentu matżeństwa dostosowane do zwyczajów diecezji polskich, Katowice 1996, nr 97; Jan Paweł II, List do rodzin, nr 10, w: Posoborowe dokumenty Kościoła katolickiego o matżeństwie i rodzinie, t. 2, red. K. Lubowicki, Kraków 1999, s. 48-51.

${ }^{24} \mathrm{FC}, 11$.

${ }^{25} L R, 18$.

${ }^{26}$ Jan Paweł II, Dobro nierozerwalności i dobro samego matżeństwa. Nie możemy ulegać men- 
o nierozerwalności małżeństwa, podobnie jak całe orędzie chrześcijańskie, jest przeznaczona dla mężczyzn i kobiet wszystkich czasów i miejsc ${ }^{27}$. Dawanie świadectwa bezcennej wartości nierozerwalności i wierności małżeńskiej jest jednym z najcenniejszych i najpilniejszych zadań małżonków chrześcijańskich w obecnych czasach $^{28}$.

O nierozerwalności małżeństwa, jako istotnym przymiocie tego związku, poucza także Katechizmu Kościoła Katolickiego. Dokument ten przypomina, że nierozerwalność małżeństwa wypływa z zamysłu Boga i wpisuje się ona w pedagogię Bożego planu zbawienia człowieka ${ }^{29}$. Potwierdza to Chrystus, który przywraca małżeństwu właściwą mu rangę, wypaczoną przez grzech, i w którym ten plan znajduje swoje zwieńczenie ${ }^{30}$. Katechizm podkreśla, że nierozerwalność małżeństwa jest zgodna z wymogiem miłości małżeńskiej, która polega na całkowitym i wzajemnym obdarowaniu osobami ${ }^{31}$. Ponieważ katechizm ma pastoralny charakter, dlatego też zwraca uwagę, że rozwody, na które zezwala prawo państwowe, mają niemoralny charakter, gdyż wprowadzają nieporządek w małżeństwo i społeczeństwo. Przyczyniają się one w ten sposób do powstania poważnych szkód ${ }^{32}$. Dlatego rozwód jest poważnym wykroczeniem przeciw prawu naturalnemu, zmierza on bowiem do zerwania dobrowolnie zawartej przez małżonków umowy, aby żyć razem aż do śmierci. Najgorsze jest jednak to, że rozwód znieważa przymierze zbawcze, którego znakiem jest małżeństwo sakramentalne ${ }^{33}$.

\section{OPINIA SPOŁECZEŃSTWA POLSKIEGO O ROZWODZIE}

Realizacja nierozerwalnego charakteru jedności małżeńskiej zależy przede wszystkim od odpowiedzialności za to samych małżonków. Z pewnością na kształtowanie tej odpowiedzialności wywierają wpływ wzorce małżeństwa propagowane przez środki społecznego przekazu oraz status związku małżeńskiego w prawodawstwie państwowym. Powoduje to powstawanie niekorzystnych postaw ludzkich, odznaczających się osłabieniem poczucia odpowiedzialności

talności rozwodowej. Audiencja w Trybunale Roty Rzymskiej z okazji inauguracji kolejnego roku pracy w Dykasterii. Przemówienie Jana Pawta II, nr 4, w: O nierozerwalności matżeństwa, Kraków 2002.

${ }^{27}$ Jan Paweł II, Dobro nierozerwalności i dobro samego matżeństwa. Nie możemy ulegać mentalności rozwodowej. Audiencja w Trybunale Roty Rzymskiej z okazji inauguracji kolejnego roku pracy w Dykasterii. Przemówienie Jana Pawta II, nr 5, w: O nierozerwalności matżeństwa, Kraków 2002.

${ }^{28} \mathrm{FC}, 20$.

${ }^{29}$ Katechizm Kościoła Katolickiego, tekst polski, Poznań 1994, nr 1610.

${ }^{30}$ KKK, 1614, 1615.

${ }^{31}$ KKK, 1643, 1644.

${ }^{32}$ KKK, 2385.

${ }^{33}$ KKK, 2384. 
za nierozerwalny charakter jedności małżeńskiej. Wyraża się to w rozpadzie małżeństw, którego najczęstszą formą jest rozwód ${ }^{34}$. Dlatego rozwód należy traktować jako efekt nieudanego związku małżeńskiego ${ }^{35}$, następstwo ciągłych konfliktów i nieporozumień, jak również braku więzi międzyludzkich. Jest on ostatnią fazą kryzysu małżeńskiego i zarazem dowodem niemożności opanowania narastających problemów przez oboje małżonków. W sensie prawnym rozwód jest usankcjonowaniem wcześniej zapoczątkowanego rozbicia małżeństwa ${ }^{36}$.

W zlaicyzowanym współcześnie społeczeństwie występują silne tendencje prorozwodowe, prowadzące do praktyki tworzenia przez osoby rozwiedzione kolejnych związków małżeńskich o charakterze formalnym lub nieformalnym. Tworzenie formalnych małżeństw porozwodowych prowadzi do wzrostu liczby małżeństw powtórnych istniejących $\mathrm{w}$ danym społeczeństwie, natomiast tworzenie porozwodowych związków nieformalnych jest przyczyną zwiększania się liczby funkcjonujących związków kohabitacyjnych ${ }^{37}$. W efekcie obu tych procesów narasta zjawisko poligamii sekwencyjnej. Ludziom o mentalności nowoczesnej trudno jest zaakceptować nierozerwalność małżeństwa ${ }^{38}$.

Wymóg nierozerwalności związku małżeńskiego jest jedną z podstawowych norm etyki katolickiej. Badania przeprowadzone przez CBOS w 1991 roku pokazały, że 43,7\% ankietowanych wypowiedziało się za nierozerwalnością małżeństwa. Za możliwością rozpadu małżeństwa opowiedziało się 15,6\% respondentów, 31,6\% badanych podkreślało rolę różnych czynników ją warunkujących, a 9,1\% nie potrafiło jednoznacznie wypowiedzieć się w tej kwestii. Podobnie wyniki uzyskane w sondażu CBOS przeprowadzonym w listopadzie w 1992 roku pokazały, że 43\% ankietowanych opowiedziało się za nierozerwalnością małżeństwa, a 48\% aprobowało rozwód ${ }^{39}$. W świetle badań przeprowadzonych przez A. Kwak w 1993 roku na grupie osób w wieku 20-62 lata z wykształceniem średnim i wyższym, 54\% ankietowanych dopuszczało możliwość rozwodu, chociaż nie popierało takiej sytuacji, 31\% respondentów uznało rozwód za przejaw postępu, a 14\% badanych wyraziło zdecydowaną dezaprobatę dla możliwości rozwodu ${ }^{40}$.

${ }^{34}$ Z. Tyszka, Rodzina wspótczesna - jej geneza i kierunki przemian, w: Rodzina wspótczesna, red. M. Ziemska, Warszawa 2001, s. 43.

${ }^{35} \mathrm{~J}$. Rostowski, Niektóre psychospołeczne uwarunkowania dezintegracji zwiazku matżeńskiego, w: Z badań nad integracja matżeństwa i rodziny, red. M. Ziemska, Warszawa 1990, s. 227; M. Kuciarska-Ciesielska, G. Marciniak, J. Paradysz, Rozpad matżeństw w Polsce - przyczyny i skutki, Warszawa 1993.

${ }^{36}$ H. Cudak, Funkcjonowanie dzieci z matżeństw rozwiedzionych, Toruń 2004, s. 8, 11.

${ }^{37} \mathrm{~K}$. Kluzowa, Matżeństwa porozwodowe w Polsce lat osiemdziesiatych, w: Stan i przeobrażenia wspótczesnych rodzin polskich, red. Z. Tyszka, Poznań 1991, s. 231.

${ }^{38}$ J. Mariański, Kryzys moralny czy transformacja wartości?, Lublin 2001, s. 343.

${ }^{39}$ CBOS, Relioijność Polaków: 1984-1994, Warszawa 1994, s. 10.

${ }^{40}$ A. Kwak, Rodzina i jej przemiany, Warszawa 1994, s. 33. 
Na podobny stosunek Polaków do rozwodu wskazują badania z lat późniejszych. Wedle sondażu OBOP z 1995 roku tylko 39\% badanych dorosłych Polaków zdeklarowało się jako zdecydowani przeciwnicy rozwodu, a $53 \%$ opowiedziało się za możliwością rozwodu. Rozwód odrzucało 41\% badanych do 19 roku życia, 27\% w wieku 30-39 lat. Częściej rozwód odrzucali respondenci mieszkający na wsi (47\%) niż w dużych miastach $(29 \%)^{41}$.

Według badań przeprowadzonych przez W. Zdaniewicza w 1996 roku, 35,5\% ankietowanych było za niedopuszczalnością rozwodów, 36,6\% uzależniało ją od różnych czynników, 20,3\% dopuszczało rozwody, a 7,6\% nie posiadało zdania na ten temat ${ }^{42}$. Wynika z tego, że ci, którzy całkowicie dezaprobują rozwód, są w zdecydowanej mniejszości. Taka proporcja budzi obawy co do właściwego stopnia odpowiedzialności małżonków za nierozerwalność ich małżeństwa.

Proporcje widoczne $\mathrm{w}$ badaniach ogólnopolskich potwierdzają także badania przeprowadzone w poszczególnych regionach Polski i grupach zawodowych $^{43}$. W świetle badań przeprowadzonych przez W. Świątkiewicza w latach 1986-1990 wśród rodzin miejskich regionu górnośląskiego, 53,9\% respondentów deklarowało uznanie dla nierozerwalności małżeńskiej, a 43,6\% opowiedziało się za możliwością rozwodu ${ }^{44}$.

Przeprowadzone w latach 1993-1995 badania przez A. Kwak wśród mieszkańców Warszawy i okolic pokazały, że 38\% respondentów opowiedziało się przeciwko rozwodowi, $22 \%$ raczej wykluczało możliwość rozwodu, $21 \%$ dopuszczało taką możliwość, a 19\% opowiedziało się za rozwodem w każdych okolicznościach. Interesujące było to, że kobiety były częściej za rozwodami niż mężczyźni ${ }^{45}$.

${ }^{41}$ OBOP, Jakie zachowania potepiamy?, Warszawa 1995, s. 2-3.

${ }^{42} \mathrm{~W}$. Zdaniewicz, Zachowania religijno-moralne. Kto przegrat? Kto wygrat? Postawy społeczno-religijne diecezjan włoctawskich '97, red. W. Zdaniewicz, T. Zembrzuski, Warszawa 1997, s. 62-63.

${ }^{43}$ P. Kryczka, Rozwód w opinii społecznej - kierunki zmian, w: Rodzina wspótczesna, s. 154. Z przeprowadzonych przez Z. Tyszkę badań w 1984 roku w poznańskim środowisku małżeństw studenckich wynikało, że około $80 \%$ studentów i studentek dopuszczało możliwość rozwodu, z tym, że około $98 \%$ uważało taką sytuację za zjawisko niewłaściwe. Chociaż podawane przyczyny rozwodu były różne, to jednak nie zmienia to faktu bardzo wysokiej tolerancyjności wobec rozwodu w tym środowisku (Z. Tyszka, Małżeństwa i rodziny studenckie, w: Analiza przemian wybranych kategorii rodzin polskich, red. Z. Tyszka, Poznań 1990, s. 131).

${ }^{44}$ W. Świątkiewicz, Religijność w życiu wspótczesnych rodzin, w: Wartości a style życia rodzin. Socjologiczne badania rodzin miejskich na Górnym Śląsku, red. W. Świątkiewicz, Katowice 1992, s. 114.

${ }^{45}$ A. Kwak, Rozwód a separacja w opinii kobiet $i$ mężczyzn, w: Rodzina wspótczesna, s. 180 . 
Wyniki uzyskane w badaniach przeprowadzonych przez J. Baniaka w 1998 roku na terenie Kalisza pokazały, że 62,3\% respondentów uznawało rozwód za całkowicie dozwolony, 3,4\% za dozwolony warunkowo, 24,4\% za całkowicie zabroniony, $4 \%$ za zabroniony częściowo, $4 \%$ nie miało własnego zdania $\mathrm{w}$ tej sprawie, a 1,9\% nie udzieliło odpowiedzi na ocenę tego czynu ${ }^{46}$.

W świetle badań przeprowadzonych przez E. Frankowskiego w 1998 roku na terenie diecezji sandomierskiej, 55,4\% respondentów opowiedziało się zdecydowanie za zachowaniem nierozerwalności małżeństwa. Natomiast 25,4\% badanych dopuszczało rozerwalność tego związku, jednak warunkowało to okolicznościami, a tylko 9,8\% ankietowanych opowiedziało się za całkowitą możliwością uzyskania rozwodu.

Na podobny trend wskazują badania z ostatnich lat. Badania przeprowadzone przez E. Frankowskiego w 2003 roku na terenie diecezji sandomierskiej pokazały, że 53,9\% respondentów uważało, iż rozwód jest niedopuszczalny, a 23,4\% uznało, że jest on dopuszczalny w zależności od okoliczności. Co do całkowitej możliwości rozerwania małżeństwa nastąpił znaczny wzrost, ponieważ opowiedziało się za nią aż 18,6\% ${ }^{47}$. Badania pokazały też, że wraz ze wzrostem wieku respondentów, wzrasta odsetek uważających rozwód za niedopuszczalny i zmniejsza się odsetek uważających, że jest on dopuszczalny, jak również wraz ze wzrostem poziomu wykształcenia wzrasta odsetek opowiadających się za rozwodem i maleje odsetek uważających go za niedopuszczalny ${ }^{48}$.

Przytoczone powyżej badania wskazują na niewielkie, ale jednak występujące zmniejszanie się wskaźnika ludzi co do ważności normy dotyczącej nierozerwalności małżeństwa. Przyczyną tego jest szerzenie się nowoczesnej mentalności, która odrzuca tę normę. Niekiedy dochodzi do traktowania tej normy moralnej jako czynnika sprzeciwiającego się wolności człowieka. Wówczas rozwód jest interpretowany wyłącznie w kategoriach świeckich, jakie nadaje małżeństwu państwowe prawo rodzinne ${ }^{49}$. Potwierdza to fakt, że blisko 55\% spośród rozwodzących się osób podjęło decyzję o rozwodzie bez brania pod uwagę, że zawarli związek małżeński w Kościele, który to związek według nauczania Kościoła jest nierozerwalny ${ }^{50}$.

Duży odsetek respondentów dopuszczających rozwody pozostaje w sprzeczności z deklarowanymi przez nich postawami religijnymi. Zazwyczaj

${ }^{46} \mathrm{~J}$. Baniak, Zmiany $w$ etosie matżeńskim $i$ rodzinnym katolików miejskich w Polsce. Studium socjologiczne, Studia Gnesnensia XV (2001), s. 395-396.

${ }^{47}$ E. Frankowski, Życie religijne w rodzinach diecezji sandomierskiej, Stalowa Wola 2005, s. 93.

${ }^{48}$ Tamże, s. 95.

${ }^{49}$ P. Kryczka, Rozwód w opinii społecznej, Studia Socjologiczne 1 (1999), s. 45-46.

${ }^{50}$ W. Majkowski, Zagrożenia wspótczesnej rodziny polskiej, w: Rodzina polska u progu trzeciego tysiaclecia, red. W. Majkowski, Warszawa 2003, s. 80. 
nie mniej niż $80 \%$ badanych stanowiły osoby wierzące, a w społecznościach mniejszych miast i wsi odsetek takich osób był jeszcze większy ${ }^{51}$. Świadczyć to może o coraz powszechniejszym zmniejszaniu się wśród wierzących akceptacji nauczania Kościoła o wymogu nierozerwalności małżeństwa, na rzecz laickiej interpretacji związku małżeńskiego. Potwierdzają to przeprowadzone w latach osiemdziesiątych i dziewięćdziesiątych XX wieku badania na temat dopuszczalności rozwodów przez Kościół. Pytano o oczekiwania respondentów na przyzwalające stanowisko Kościoła w dopuszczaniu rozwodów. Dało się zauważyć wyraźne przesunięcie postaw z kategorii negatywnych do kategorii optujących za pozytywnym ustosunkowaniem się Kościoła do rozwodów ${ }^{52}$. Można odnotować także prawidłowość, że im większa zbiorowość, tym częściej występują w niej postawy prorozwodowe. Optymizmem napawa fakt, że 46,7\% narzeczonych wyklucza możliwość rozwodu.

Chociaż istnieje wiele okoliczności rozpadu małżeństwa, zarówno społecznych, jak i psychologicznych, to najbardziej istotnymi przyczynami rozwodów, podawanymi przez badanych, jest: niezgodność charakterów, zdrada, nadużywanie alkoholu, konflikty, różnice poglądów, niedobór seksualny, dłuższa nieobecność ${ }^{33}$. Szczególnie ważną przyczyną rozwodów jest niedojrzałość psychiczna małżonków, którzy w rozwodzie upatrują pewnego wyjścia z kryzysowej, pełnej napięć i stresów sytuacji życia małżeńskiego ${ }^{54}$. Ponadto, niedojrzałość ta wyraża się w brakach intelektualnych (niezdolność do kierowania się rozsądkiem i brak umiejętności przewidywania skutków podejmowanych decyzji) i emocjonalnych (niedojrzałość do współżycia małżeńskiego, niestałość i zmienność nastrojów). Fakt, że duża część respondentów opowiedziała się za rozwodem w przypadku zaistnienia powyższych okoliczności, pozwala przypuszczać, że ważniejsze dla nich jest wówczas własne szczęście i zadowolenie osobiste, aniżeli podejmowanie działań zmierzających do zachowania trwałości małżeństwa.

Około 74\% wszystkich spraw rozwodowych jest kierowanych do sądu przez kobiety. Zjawisko to dotyczy wszystkich kategorii społecznych, począwszy od bogatych czy biednych, różnych poziomów wykształcenia małżonków poprzez różne wyznania, a skończywszy na różnych kulturach i miejscach zamieszkania ${ }^{55}$. Zazwyczaj większość spraw rozwodowych kończy się bez

${ }^{51}$ P. Kryczka, Rozwód w opinii społecznej - kierunki zmian, w: Rodzina wspótczesna, s. 156.

52 Tamże, s. 160-161.

${ }^{53}$ J. Żebrowski, Wspótczesne przeobrażenia w funkcjonowaniu rodziny polskiej, w: Rodzina polska na przetomie wieków, red. J. Żebrowski, Gdańsk 2002, s. 20; M. Winiarski, Zaburzenia w funkcjonowaniu rodziny $i$ ich impikacje, w: Rodzina polska na przełomie wieków, s. 65.

${ }^{54}$ H. Cudak, Funkcjonowanie dzieci z matżeństw rozwiedzionych, s. 11.

55 Tamże, s. 14. 
orzekania o winie którejś ze stron ${ }^{56}$, ponieważ takie postępowanie jest mniej skomplikowane i trwa znacznie krócej, co tym samym oznacza możliwość szybszego otrzymania rozwodu.

Wyniki uzyskane w badaniach na temat dopuszczalności rozwodów w sytuacjach szczególnych i badań przeprowadzonych wśród różnych społeczności na terenie Polski pokazały, że respondenci uwzględniali różne okoliczności przy podejmowaniu decyzji o rozwodzie. Na pierwszym miejscu, jako okoliczność skłaniająca do rozwodu, było stawiane uporczywe pijaństwo małżonka, bicie lub znęcanie się nad współmałżonkiem czy też dziećmi, jak również całkowity rozkład pożycia małżeńskiego. Za takim rozwiązaniem opowiedziało się ponad $90 \%$ respondentów z wielkich miast, natomiast $\mathrm{w}$ pozostałych zbiorowościach takie rozwiązanie wskazało około 70\%, z wyjątkiem badanych wsi, gdzie wskaźnik ten był jeszcze niższy.

Na drugim miejscu, jako rodzaj okoliczności dopuszczających rozwód, respondenci postawili sytuację, w której oboje małżonkowie doszli do wniosku, że lepiej im będzie żyć oddzielnie, lub wówczas, gdy występuje odmowa dostarczania środków na utrzymanie. Takie rozwiązanie podało około 50-70\% ankietowanych, przy czym w latach dziewięćdziesiątych dała się zauważyć tendencja wzrostowa takiego rozwiązania. Dopiero na trzecim miejscu, jako okoliczność skłaniająca do podjęcia decyzji o rozwodzie, została postawiona przez respondentów zdrada małżeńska, nieudane współżycie seksualne lub niezgodność charakterów. W badanych zbiorowościach za taką opcją opowiedziało się około $50 \%$ respondentów ${ }^{57}$.

Ważną przyczyną podawaną przez badanych, wpływającą na dysharmonię pomiędzy małżonkami, co ostatecznie doprowadziło do rozwodu, był brak przygotowania do małżeństwa. Aż 50\% respondentów stwierdziło taki stan rzeczy, a 29\% uznało, że byli właściwie przygotowaniu do życia małżeńskiego $^{58}$. Ponadto $45 \%$ badanych zdeklarowało brak wizji swego małżeństwa, a nawet nie przejawiało potrzeby jej posiadania ${ }^{59}$. Musi budzić zdziwienie i niepokój fakt, że chociaż zawarcie związku małżeńskiego należy do jednej z najważniejszych decyzji w życiu człowieka, to jednak narzeczeni przygotowaniu

${ }^{56} \mathrm{~W} 1995$ roku rozwody takie stanowiły 68,2\% wszystkich rozwodów, w 1996 roku 68,5\%, w 1997 roku 68,6\% i w 1999 roku 69,3\%.

${ }^{57}$ P. Kryczka, Rozwód w opinii społecznej - kierunki zmian, w: Rodzina wspótczesna, s. 163-164. Badania przeprowadzone przez W. Majkowskiego w 1995 roku i dotyczące przyczyn rozwodów pokazały, że oficjalnie na pierwszym miejscu znalazł się alkoholizm, a na dalszych miejscach niewierność małżeńska i niezgodność charakterów. W rzeczywistości pierwszym powodem rozwodów była zdrada małżeńska, a potem alkoholizm (W. Majkowski, Czynniki dezintegracji wspótczesnej rodziny polskiej, Kraków 1997, s. 131-132).

${ }^{58}$ W. Majkowski, Czynniki dezintegracji wspótczesnej rodziny polskiej, s. 159.

${ }_{59}$ Tenże, Zagrożenia wspótczesnej rodziny polskiej, w: Rodzina polska u progu trzeciego tysiąclecia, s. 24 . 
do małżeństwa poświęcają stosunkowo mało uwagi. Ponadto przygotowanie takie jest często niewłaściwie rozumiane, ponieważ zostaje ono zawężone do załatwienia formalności związanych z zawarciem małżeństwa, a nie do formacji psychicznej i duchowej.

Co się tyczy niezaspokajania potrzeb wyższych w małżeństwie jako przyczyny rozwodu, to badania z lat 1995-1996 przeprowadzone przez W. Majkowskiego wśród osób rozwiedzionych pokazały, że w ocenie respondentów żadna z nich nie była zadowolona z pożycia małżeńskiego u znacznej części małżeństw. W pełni były zaspokojone te potrzeby tylko u niewielkiej części małżonków ${ }^{60}$. Badania wskazują bądź na brak znajomości tego zagadnienia lub brak dobrej woli, czyli postawę egoizmu i koncentracji na własnej osobie, a nie na osobie współmałżonka. Ponieważ współczesne małżeństwo bardziej opiera się na więzach emocjonalnych, łatwo rozpada się przy braku satysfakcji ze związku małżeńskiego ${ }^{61}$.

W świetle badań przeprowadzonych przez H. Cudaka w 1999 roku, głównymi przyczynami rozwodów była: niezgodność charakterów (28,9\%), niedochowanie wierności małżeńskiej (26,4\%) i nadużywanie alkoholu $(25,7 \%)^{62}$. Natomiast badania z lat 1999-2000 wśród małżeństw rozwiedzionych pokazały, że głównymi przyczynami rozwodów były: alkoholizm małżonka (35,1\% odpowiedzi respondentów), niezgodność charakterów (29,3\%), agresja męża lub żony $(15,2 \%)$ oraz zdrada małżeńska $(14,1 \%)^{63}$. Co się tyczy alkoholizmu jednej ze stron małżeństwa jako przyczyny rozwodów, to najwięcej przypadków odnotowano w przedziale wiekowym pomiędzy 30-40 lat (67,5\%) oraz pomiędzy 20-30 lat (27,3\%), natomiast najmniej pomiędzy 40-50 rokiem życia (5,2\%). Z kolei biorąc pod uwagę niezgodność charakterów jako przyczynę rozwodów, to najwięcej przypadków było w kategorii stażu małżeńskiego pomiędzy 1-7 rokiem (51,8\%) oraz w latach 8-14 (23,5\%). Najmniej takich przypadków odnotowano w latach 15-21 (17,3\%) oraz 22-30 (7,4\%). Co się tyczy niewierności małżeńskiej jako przyczyny rozwodów, to największe natężenie tego zjawiska zaobserwowano w przypadku małżeństw ze stażem małżeńskim 15-21 lat (46,2\%) oraz 22-30 (30,8\%), a najmniejsze ze stażem do lat 7 (5,1\%) i w latach $8-14(17,9)^{64}$.

${ }^{60} \mathrm{~W}$ świetle badań W. Majkowskiego przedstawiało się to następująco: potrzeba miłości u 14,2\% badanych, potrzeba bezpieczeństwa u 6,2\%, potrzeba zrozumienia u 6,2\%, potrzeba zaufania u 7,4\%, potrzeba pomocy u 6,8\%, potrzeba intymnego współżycia u 35,2\% (W. Majkowski, Czynniki dezintegracji wspótczesnej rodziny polskiej, s. 173).

\footnotetext{
${ }^{61}$ A. Kwak, Rodzina $w$ dobie przemian. Matżeństwo i kohabitacja, s. 37.

${ }^{62}$ H. Cudak, Funkcjonowanie dzieci z matżeństw rozwiedzionych, s. 17.

63 Tamże, s. 62.

64 Tamże, s. 65, 70, 74 .
} 
Mówiąc o odpowiedzialności małżonków za trwałość ich związku, należy wskazać, że istotną przyczyną rozpadu małżeństwa jest brak możliwości skorzystania przez małżonków z fachowego poradnictwa w momencie pojawienia się pierwszych konfliktów ${ }^{65}$. Badania socjologiczne pokazały, że 58,6\% małżonków przeżywających poważny kryzys ich związku zdeklarowało, że u nikogo nie szukało pomocy $\mathrm{w}$ trudnościach małżeńskich. Były to więc małżeństwa skazane w kryzysie na samych siebie. Wydaje się, że taki wynik wskazuje na powszechnie jeszcze panujące błędne przeświadczenie, iż sprawy małżeńskie należą wyłącznie do sfery prywatnej. Pozostała część respondentów, która szukała pomocy w sytuacjach kryzysu małżeńskiego, zdeklarowała, że najpierw pomocy szukała u członków najbliższej rodziny (54,8\%), u księdza (21,2\%), w poradniach specjalistycznych $(17,5 \%)$ i innych osób $(6,5 \%)^{66}$.

Z badań przeprowadzonych w latach 1994-1996 wynika, że głównymi autorytetami branymi pod uwagę przez respondentów w szukaniu pomocy w sytuacjach trudnych w małżeństwie byli najczęściej członkowie rodziny, przyjaciele, znajomi oraz ksiądz ${ }^{67}$. Taki wynik może świadczyć o oddzielaniu nauczania Kościoła o małżeństwie od codziennego życia.

Niepokojące jest to, że ocena możliwości rozwodu jeszcze gorzej wygląda u młodzieży, która wkracza w etap zawierania związków małżeńskich ${ }^{68}$. W badaniach z 1992 roku, przeprowadzonych wśród młodzieży klas ósmych, licealistów i studentów, 78,0\% respondentów aprobowało rozwody, w tym 47,0\% dopuszczało je w każdej sytuacji. Według badań J. Mariańskiego z 1994 roku, przeprowadzonych wśród młodzieży szkół maturalnych, 42,2\% ankietowanych odrzucało możliwość rozwodu, w tym 14,2\% całkowicie, 13,6\% z pewnymi wyjątkami, a 14,4\% uważało, że musi być on uzasadniony poważną przyczyną ${ }^{69}$. Znacznie częściej odrzucała możliwość rozwodu młodzież spełniająca często praktyki religijne ${ }^{70}$.

${ }^{65}$ Pełnomocnik Rządu do Spraw Rodziny, Raport o sytuacji polskich rodzin, s. 27.

${ }^{66}$ W. Majkowski, Czynniki dezintegracji wspótczesnej rodziny polskiej, s. 161.

${ }^{67}$ P. Kryczka, Rozwód w opinii społecznej - kierunki zmian, w: Rodzina wspótczesna, s. $157-158$.

${ }^{68}$ Badania przeprowadzone pod koniec lat osiemdziesiątych przez A. Kwak w środowisku wiejskim wśród dziewcząt z klas ósmych pokazały, że ponad połowa, bo około 55\% ankietowanych, pozytywnie ocenia instytucję rozwodów. Chociaż rozwód jest źle oceniany w tym środowisku, to jednak osoby te zdecydowałyby się na tę trudną sytuację (A. Kwak, Rodzina i jej przemiany, s. 35). Z kolei badania ogólnopolskie przeprowadzone przez W. Zdaniewicza w 1988 roku wśród młodzieży szkół ponadpodstawowych i studentów pokazały, że tylko 21,8\% ankietowanych akceptuje wymóg nierozerwalności małżeństwa (W. Zdaniewicz, Model religijności uczniów i studentów, w: Religia w dobie przetomu w Polsce, red. L. Adamczuk, Warszawa 1991, s. 148).

${ }^{69} \mathrm{~J}$. Mariański, Młodzież pomiędzy tradycją i ponowoczesnością, Lublin 1995, s. 132-133.

${ }^{70}$ Tenże, Praktyki religijne młodzieży a uznawane wartości prorodzinne, w: Rodzina wspótczesna, s. 138. 
Z badań W. Zdaniewicza przeprowadzonych w drugiej połowie lat dziewięćdziesiątych, wynika, że 21,4\% młodzieży szkół średnich uważało normę nierozerwalności małżeństwa za nienaruszalną, 42,4\% warunkowało ją zaistniałymi okolicznościami, a 28,2\% opowiedziało się za możliwością rozwodu ${ }^{71}$. Badania przeprowadzone przez K. Pawlinę w 1997 roku wśród młodzieży szkół średnich pokazały, że 28,2\% respondentów dopuszczało możliwość rozwodu, $42 \%$ uzależniało to od okoliczności, a tylko 21,4\% wykluczało rozwód ${ }^{72}$.

Badania J. Mariańskiego z lat 1997-2000 wśród młodzieży szkół średnich pokazały, że 17,1\% (w poszczególnych przypadkach od 10,3 do 25,2\%) respondentów opowiedziało się za dopuszczalnością rozwodów, 43,9\% aprobowało z zastrzeżeniami możliwość rozwodu, a tylko 27,9\% nie akceptowało rozwodów ${ }^{73}$. Kobiety rzadziej niż mężczyźni uznawały rozwody za niedozwolone. W świetle tych badań, najgorzej pod względem odrzucenia normy nierozerwalności małżeństwa wypadli rozwiedzeni, ponieważ tylko 8,5\% spośród nich opowiedziało się za nierozerwalnością małżeństwa, co chyba jest raczej zrozumiałe $^{74}$.

Powyższe zestawienie dotyczące oceny moralnej rozwodów pozwala wnioskować, że poziom akceptacji tej normy moralnej nie koresponduje z deklarowanym poziomem religijności. Wskazuje to na duży stopień selektywności w spełnianiu tego wymogu, wynikającego z podjętych zobowiązań małżeńskich. Trend prorozwodowy w społeczeństwie polskim jest w dużej mierze następstwem coraz bardziej nasilających się tendencji laicyzujących. Tendencje te utrudniają osiągnięcie dojrzałości psychicznej, czego wyrazem jest brak troski o drugiego człowieka i nadmierna koncentracja na zaspokajaniu wyłącznie swoich potrzeb. Prowadzi to do spłycenia więzi pomiędzy małżonkami i w ten sposób przyczynia się do narastania konfliktów małżeńskich, które są obecnie głównym powodem rozwodów. Inną przyczyną doprowadzającą do rozwodów jest brak należytego przygotowania narzeczonych do małżeństwa, co w dużej mierze jest następstwem braku przywiązywania należnej uwagi przez nich samych do ważności tego przygotowania.

Badania socjologiczne, zarówno ogólnopolskie, jak i regionalne, pokazują, że prawie połowa respondentów opowiada się za możliwością rozwodu, chociaż część z nich warunkowała go określonymi okolicznościami, przy czym tendencja prorozwodowa była bardziej widoczna w zbiorowościach większych niż mniejszych. Wyrazem braku odpowiedzialności małżonków za ich związek

${ }^{71}$ W. Zdaniewicz, Moralność religijna, w: Religijność Polaków 1991, red. L. Adamczuk, W. Zdaniewicz, Warszawa 1993, s. 69.

${ }^{72}$ K. Pawlina, Polska młodzież przełomu wieków, Warszawa 1998, s. 65.

${ }^{73}$ J. Mariański, Wartości prorodzinne w świadomości młodzieży szkolnej, w: Rodzina polska u progu trzeciego tysiaclecia, red. W. Majkowski, Warszawa 2003, s. 235-236.

${ }^{74}$ R. Sztychmiler, Istotne obowiazki małżeńskie, Warszawa 1997, s. 312-313, 331-332. 
było także to, że $w$ przypadku zaistnienia sytuacji mogącej doprowadzić do rozpadu małżeństwa, bardzo niewielu z nich zdeklarowało chęć skorzystania z pomocy oferowanej im przez poradnie specjalistyczne.

Najbardziej niepokojące jest jednak to, że akceptację rozwodów deklarowała duża część badanej młodzieży, choć akceptacja ta zależała od stopnia religijności. Zjawisko to musi budzić uzasadnione obawy o poczucie odpowiedzialności za nierozerwalność małżeństwa wśród osób, które wkrótce będą wstępować w związki małżeńskie.

\section{KSZTAkTOWANIE ODPOWIEDZIALNOŚCI ZA NIEROZERWALNOŚĆ MAŁŻEŃSTWA}

Spośród wielu przyczyn powodujących obecnie rozpad małżeństwa, najważniejszą wydaje się zanikanie odpowiedzialności małżonków za ich związek, który jest następstwem zmniejszania się świadomości ludzi o ważności normy dotyczącej nierozerwalności małżeństwa.

Trend prorozwodowy jest $\mathrm{w}$ dużej mierze następstwem nasilającej się laicyzacji, utrudniającej osiągnięcie dojrzałości osobowej i związanej z nią odpowiedzialności za małżeństwo, które zaczyna być postrzegane w kategoriach wzajemnego świadczenia sobie usług $\mathrm{w}$ zakresie zaspokojenia swoich potrzeb. Wymownym tego przykładem jest coraz większa przychylność i życzliwe nastawienie do związków konkubinackich. Z sytuacji tej wynika duszpasterski postulat, aby wobec małżeństw podjąć działania, które obudzą w małżonkach poczucie większej odpowiedzialności za nierozerwalny charakter jedności małżeńskiej i tym samym ograniczą możliwość rozpadu ich małżeństwa.

Wielość przyczyn powstawania zjawiska rozwodów, ich uwarunkowania oraz indywidualność każdego małżeństwa, znajdującego się w takiej sytuacji, stawia przed duszpasterstwem rodzin zadanie zawiązywania i koordynowania współpracy specjalistów z różnych dziedzin, które mogłyby jak najskuteczniej przyjść z pomocą małżonkom doświadczającym trudności w zakresie trwałości związku małżeńskiego ${ }^{75}$. Postuluje się przywiązywanie większej uwagi zwłaszcza do pracy takich specjalistów, jak: pedagodzy, psychologowie, prawnicy, lekarze i pracownicy społeczni ${ }^{76}$. Dzięki bardziej intensywnemu wykorzystaniu ich wiedzy, doświadczenia i wzajemnej współpracy, możliwe stałoby się dokładniejsze rozeznawanie sytuacji małżeństwa zagrożonego rozpadem i przez to duszpasterstwo mogłoby być bardziej efektywne w zakresie zindywidualizowania pomocy małżonkom przeżywającym kryzys. Aby działaniom specjalistów

\footnotetext{
${ }^{75}$ J. Buxakowski, Wprowadzenie do teologii duszpasterstwa rodzin, Pelplin 1999, s. 105.

${ }^{76}$ Konferencja Episkopatu Polski, Dyrektorium duszpasterstwa rodzin, Warszawa 2003, s. 17.
} 
nadać właściwy i pogłębiony kontekst, wychodzący poza płaszczyznę doczesną, należy wcześniej zadbać o ich rzetelną formację religijną, a także wiedzę z zakresu teologii małżeństwa i nauki Kościoła o małżeństwie katolickim. W ramach tej formacji należałoby przypominać, że pomoc niesiona przez specjalistów jest zaszczytnym posłannictwem. Służy ona szlachetnemu celowi, jakim jest dobro małżeństwa, będące fundamentem społeczeństwa i skarbem Kościoła. Fachowość specjalistów, połączona z osobistym świadectwem ich życia, uczyni duszpasterstwo małżeństw bardziej kompetentnym. Trwałość jedności małżeńskiej jest przecież realizacją zamysłu Bożego wobec tej wspólnoty.

Przedstawione powyżej zadania duszpasterstwa rodzin na rzecz zachowania trwałości związków małżeńskich są zgodne z postulatem integracji i współpracy w posłudze pastoralnej. Racja takiej współpracy wynika z faktu, że rzeczywistość małżeństwa i rodziny jest złożona, dlatego działanie dla ich dobra powinno być wieloaspektowe. Nie może ono być przypisane tylko jednemu wykonawcy, lecz powinno być troską obowiązującą wszystkich ludzi ${ }^{77}$. Nie umniejsza to wcale roli i znaczenia tych, którzy z racji swego powołania w sposób szczególny odpowiedzialni są za duszpasterstwo rodzin. Dotyczy to zwłaszcza kapłana, będącego ze swej natury duszpasterzem małżeństw i rodzin ${ }^{78}$. Ma on specyficzną rolę, która wynika $z$ faktu, że jego zadaniem jest głoszenie Bożej prawdy, aby w ten sposób pomóc ludowi Bożemu w wyrobieniu sobie zmysłu wiary ${ }^{79}$. To stawia przed nim wymaganie posiadania właściwej wizji małżeństwa i działalności pastoralnej, dzięki którym będzie on zachęcał do współpracy, koordynował i pomagał w programowaniu duszpasterstwa rodzin. Jest to zarazem zachęta dla niego do specjalistycznego przygotowania, aby efektywniej spełniać posługę mu powierzoną.

W duszpasterstwie rodzin nie można pominąć roli samych małżeństw i rodzin, których świadectwo życia bogaci posługę pastoralną. Dzięki temu staje się ona bardziej przekonująca i skuteczna. Udział ludzi świeckich w duszpasterstwie rodzin jest istotny, ponieważ opiera się na zasadzie ich kompetentnego działania.

Celem integracji i współpracy w duszpasterstwie rodzin jest zabezpieczenie się przed działaniami wyizolowanymi. Podzielenie posługi małżeństwom na niezależne od siebie działania spowodowałoby jej nieskuteczność ${ }^{80}$. Stąd też, w poszczególnych działaniach pastoralnych, należy uwzględniać całościową wizję, co sprzyja współdziałaniu i współpracy. Takiej współpracy domaga się natura małżeństwa i rodziny oraz jej posłannictwo w Kościele i świecie.

${ }_{77}^{7 D K}, 52$.

${ }^{78} \mathrm{~J}$. Buxakowski, Wprowadzenie do teologii duszpasterstwa rodzin, s. 174.

${ }^{79} \mathrm{FC}, 73$.

${ }^{80}$ J. Wilk, Duszpasterstwo rodzin: zasady praktycznego dziatania, RTK 33 (1986), z. 6, s. 107 
Istotnym obecnie zadaniem działalności pastoralnej, wobec dużej selektywności w podejściu do wymogu nierozerwalności małżeństwa, jest kształtowanie w małżonkach poczucia odpowiedzialności za nierozerwalność związku małżeńskiego. Pomocą w tym mogą być działania mające podstawę we współpracy specjalistów, które pozwolą małżonkom dostrzec złożoność przyczyn składających się na zaistniałe trudności małżeńskie. Poznanie tych przyczyn oraz pogłębiona refleksja nad nimi pomogą małżonkom przełamać postawy egoistyczne, prowadzące zazwyczaj do decyzji zerwania związku małżeńskiego. Działania, o których mowa powyżej, powinny być podjęte przez parafialne poradnie rodzinne w przypadku większych parafii, do których zaliczają się parafie miejskie, lub w przypadku parafii mniejszych, jakimi są parafie wiejskie, przez poradnie dekanalne.

Powyżej przeprowadzone analizy pokazuja, że nauczanie Kościoła katolickiego o nierozerwalności małżeństwa, która jest ważnym przymiotem związku małżeńskiego, mającym na celu dobro małżonków i społeczeństwa, nie ma adekwatnego przełożenia na życie Polaków. Wyniki badań socjologicznych pokazują coraz większą przychylność społeczeństwa polskiego dla możliwości rozerwania małżeństwa, czego konsekwencją jest wzrastająca liczba rozwodów, co świadczy o zmniejszającym się poczuciu odpowiedzialności małżonków za nierozerwalność ich związku. Obecnie znaczenie małżeństwa i wartości z nim związanych jest mocno podważane.

Zjawisko to nasiliło się w Polsce zwłaszcza w ostatnich latach. Świadczy to wyraźnie o niskim poziom akceptacji przez małżonków normy nierozerwalności małżeńskiej. Trend prorozwodowy wzmacnia nasilająca się laicyzacja, eliminująca religijny wymiar małżeństwa i nadprzyrodzoną inspirację nierozerwalności tego związku, co jeszcze bardziej osłabia w małżonkach odpowiedzialność za trwałość małżeństwa. Małżeństwo przestaje być traktowane jako umowa na całe życie, a zaczyna być uznawane jako związek, który można rozwiązać w okolicznościach utrudniających zaspokajanie własnych potrzeb. Wskazuje to na rozszerzanie się mentalności konsumpcyjnej także na małżeństwo. Potwierdzeniem jest przychylne nastawienie dużej części respondentów do możliwości uzyskania rozwodu, mimo wskazania przez nich okoliczności go warunkujących. Tendencja prorozwodowa wskazuje na coraz większą indywidualizację zasad moralności i wybiórczość w przyjmowaniu nauczania Kościoła o nierozerwalności małżeńskiej. Zanika u wiernych zdolność dostrzegania istotnych elementów moralności małżeńskiej.

Wobec tej sytuacji potrzebne jest podjęcie przez duszpasterstwo rodzin działań zmierzających do wzmacniania nierozerwalności małżeńskiej. Przede wszystkim, należy przypominać katolikom, że małżeństwo ma charakter nadprzyrodzony, co oznacza, że jest włączone w zbawcze plany Boga. Ważna jest w tym również specjalizacja pomocy udzielanej małżeństwom zagrożonym 
rozpadem, która pozwoli małżonkom uważniej przyjrzeć się powstałym problemom i tym samym zmienić swoje przychylne nastawienie do rozerwalności małżeństwa, a co za tym idzie, zbyt pochopnych decyzji w tej dziedzinie.

\section{A MORAL OPINION ABOUT A DIVORCE IN POLISH SOCIETY AND PASTORATE OF FAMILIES}

\section{SUMMARY}

Marriage is a relationship of a covenant character, that is voluntary agreement of two parties, whose contracting motive is love consisting in complete and mutual dedication. Inseparability, whose basis is good of spouses and society, is an important characteristic of marital unity. Marital inseparability ensures stability, of marital unity, and through this, of social order. Divorce is contrary to God's plan with regard to marriage, because it destroys marital unity. Difficulties with realization of the postulate of inseparability of marital unity are evident. Pro-divorce trend is reinforced by increasing secularization, eliminating religious dimension of marriage and preternatural inspiration of this relationship inseparability. Marriage is no longer treated as a contract for the entire life but regarded as a relationship, which might be dissolved when circumstances make fulfillment of one's needs difficult. Thus, it is necessary for pastorate of families to reinforce inseparability of marriage through specialization and coordination, resulting from complexity and multiplicity of reasons leading to divorce, of assistance for marriages threatened with disintegration is also very important. It is necessary to support marriages in especially difficult situations, like those forced to emigrate, ideologically divided and living in separation or new civil relationships, within the framework of reinforcing marital inseparability. 